\title{
The British Polar Year Expedition, I932-33
}

$\mathrm{O}^{\mathrm{N}}$ the ground that the relatively meagre scientific results from previous polar expeditions were due to their sporadic occurrence, Lieut. Weyprecht, of Austria, proposed in 1875 that an effort should be made to organise a number of simultaneous expeditions which would cooperate on a uniform plan over a full year. The result was the organisation of what has come to be called the First International Polar Year, 1882-83, when fourteen expeditions were sent out by twelve different countries, twelve to high northern latitudes and two to the Antarctic. Great Britain collaborated with Canada in establishing a station at Fort Rae, on the north arm of the Great Slave Lake. All the stations were fully equipped with such instruments as were then available for comprehensive meteorological and magnetic observations; they worked on a common pre-arranged plan. Judged from the practical results and the large number of researches that have been based on the data collected during that First Polar Year, the venture was entirely successful.

Since 1882, progress in meteorology, terrestrial magnetism, and allied lines of investigation has developed apace, and many problems dependent for their solution on a repetition of just such a co-operative network of stations as set up in the First Polar Year, but using improved and more refined methods of recording and observation, have presented themselves. It was felt that there could be no more fitting celebration of the jubilee of the first international year than by repeating it, and in 1929, on a proposal of Admiral Dominik of the Deutsche Seewarte, the International Meteorological Conference undertook to organise a Second Polar Year. The International Union of Geodesy and Geophysics, at its meeting at Stockholm in the same year, endorsed the proposal and promised financial aid. An International Commission for the Polar Year, 1932-33, was set up, with Dr. la Cour of the Danish Meteorological Service, as president. National committees were appointed in each country to organise the several contributions in these countries in collaboration with the International Commission.

In Britain the National Polar Year Committee, with Sir Henry Lyons as chairman, represents the interests of the Royal Societies of London and Edinburgh, as well as most of the other societies and institutions interested in such work. The Government, through the Meteorological Office, Air Ministry, has promised a grant-in-aid not exceeding $£ 10,000$ to the Polar Year efforts in Great Britain, and this has been supplemented by many generous donations in instrumental and food equipment by British manufacturers and wholesale firms.

Because it was strongly recommended by the International Commission that, so far as possible, the original Polar Year stations should be reoccupied, the British National Committee decided to send a party to the Fort Rae site on the Great Slave Lake. [Canada this year will organise her own Polar Year programme: the main station will be established at Chesterfield Inlet, with probably a second at Copper Mine for photographic auroral work.] The reopening of the mountain observatory on Ben Nevis was also considered, but questions of cost and doubts as to the real value to be obtained from only a year's further observations led to that part of the programme being dropped. Efforts were to be concentrated in equipping very fully the Canadian station at Fort Rae, and to reinforcing the observational facilities at key stations in the British Isles for meteorological and auroral work. At a later stage it was decided that advantage should be taken of opportunities for getting a complete survey of the variations in the magnetic field at high latitudes, and also auroral observations and photographs from the same stations, to establish a station for measurements of the ionisation content and its variations in the conducting regions of the upper atmosphere. It has now been decided that Prof. E. V. Appleton will take a fully equipped party to Tromsö this summer for such work, and the party will continue to observe throughout most of the Polar Year period.

The programme of observational activities drawn up by the International Polar Year Com. mission is concerned almost wholly with meteorology, terrestrial magnetism, aurora, and, to a less extent, atmospheric electricity. In each of these subjects the equipment of the British party to Fort Rae will be complete. In addition to maintaining continuous records of all the meteorological elements by autographic instruments, much attention will be given to the investigation of the conditions in the lower levels of the atmosphere by observational and instrumental methods. Frequent pilot balloon ascents will give an insight into the circulation over that part of north-west Canada, and special efforts will be directed to penetrating the stratosphere by sounding balloons on certain days each month previously selected by the International Commission. To obtain the most useful information about the temperature conditions up to and, if possible, well beyond the tropopause will necessitate the sounding balloon with its attached self-recording meteorograph ascending to $12 \mathrm{~km}$. at least. The recovery of the instrument bearing the record after the apparatus has fallen in the difficult country around the Lake is one of the problems connected with the expedition not yet solved.

For the work in terrestrial magnetism the expedition will be equipped with alternative sets of absolute instruments, a Smith portable magnetometer and earth inductor representing the modern methods, and a Kew unifilar magnetometer and a dip circle representing the older technique. For the continuously recording instruments the intention is to take three complete sets of magnetographs, each independently capable of recording by photographic means the variations in the three components of the earth's field. Of these, two sets have been specially designed for high latitude

No. 3254, VoL. 129] 
work by Dr. la Cour, Copenhagen, and will supply the standard and special quick-run traces respectively. By running a third set of variometers at low sensitivity it is hoped to ensure that even in the biggest perturbations of the field during magnetic disturbance no trace will be lost. The provision of a double set of absolute instruments is intended not to cater for emergencies alone; the present Fort Rae, which will be the main base of the expedition, is some seventeen miles farther up the north arm of the Great Slave Lake than the settlement of fifty years ago. For such purposes as establishing the secular change in the magnetic elements it will therefore be necessary to carry out sets of parallel observations at this subsidiary station.

The necessity for occasional occupation of the old Fort Rae site will be turned to further useful account by equipping the sledge party which will travel there in the winter months with a spare auroral camera, and by having some means of communication between the two bases. In this way it is hoped to use the two posts as base line stations for photography of aurora, and so to provide data for determining its height by the well-known methods developed by Prof. Störmer. It is of interest to observe in this connexion that, so far as is known, Fort Rae is very near to the zone of maximum frequency of aurora.

These three fields of meteorology, terrestrial magnetism, and aurora constitute the primary work of all the Polar Year stations, but, in addition, the party at Fort Rae hopes to obtain very complete information regarding the atmospheric electrical and allied phenomena of the region. Using a Benndorf electrograph, continuous records of the potential gradient of the earth's electric field will be kept; and equipment will be taken to observe, whenever opportunity allows, the conductivity of the air and the air-earth current using a modified Wilson electrometer, the small ion content of the air using a modified Ebert apparatus, the nucleus content with the standard Aitken instrument, and, if possible, the rate of production of atmospheric ionisation with an apparatus specially designed at Kew Observatory.

The Fort Rae party will consist of six men under the leadership of Mr. J. M. Stagg of the Meteorological Office. They will leave England about the middle of May of this year and proceed via Montreal to Edmonton. North of Edmonton the route will lie down the River Athabasca to the lake of that name, and then down the Slave River, past the seventeen miles of rapids between Fitzgerald and Fort Smith, to Fort Resolution on the south side of the Great Slave Lake, thence across the body of the lake and up the north arm nearly to its most northern extremity. This should be reached by the third week in June, thus giving time to erect the special non-magnetic huts required for the absolute observations and continuous registration of the magnetic field and instal the instrumental equipment in readiness for the official starting date of the Second Polar Year on Aug. 1. The party will continue observing until as late in August 1933 as may be safely done without undue risk of being frozen in for the next winter.

\section{The Drumm Traction Battery}

\section{By Prof. A. J. Allmand, F.R.S.}

W IDE interest has recently been aroused by reports of the successful trials of an electric train propelled by a Drumm transport battery, as also by certain details concerning the battery itself which have been made public. During the last two years I have had ample opportunity of examining and experimenting with the Drumm cell at various stages of its evolution, and it seems desirable now to put on record a statement of its main electrochemical features.

It is an alkaline cell, and the only metals which enter into its construction are stainless steel, pure nickel, and, at present, nickelled steel. Its mechanical strength and so forth are correspondingly satisfactory. As in other successful alkaline batteries, the positive plate system consists of the $\mathrm{Ni}(\mathrm{OH})_{2}$ $-\mathrm{Ni}(\mathrm{OH})_{3}$ mixture first developed by Edison; several types of such positives have been employed. Whereas, however, in other cells, the negative plate system is essentially $\mathrm{Fe}-\mathrm{Fe}(\mathrm{OH})_{2}$, it consists of $\mathrm{Zn}-\mathrm{Zn}(\mathrm{OH})_{2}$ in the Drumm battery. Moreover, $\mathrm{Zn}(\mathrm{OH})_{2}$ is soluble in alkali, whilst $\mathrm{Fe}(\mathrm{OH})_{2}$ is not. Consequently, instead of containing a solid hydroxide which becomes reduced to metal on charge, the Drumm negatives consist of nickel gauze grids, immersed in the solution of zinc oxide in potash constituting the electrolyte, and these on charge become coated with metallic zinc. The cell reactions in this 'zine' accumulator, written in their simplest form, are consequently

$$
2 \mathrm{NiO}+\mathrm{HZnO}_{2}^{\prime} \underset{\text { Discharge }}{\stackrel{\text { Charge }}{\longrightarrow}} \mathrm{Ni}_{2} \mathrm{O}_{3}+\mathrm{Zn}+\mathrm{OH}^{\prime}
$$

as compared with

$$
2 \mathrm{NiO}+\mathrm{FeO} \underset{\text { Discharge }}{\stackrel{\text { Charge }}{\rightleftarrows}} \mathrm{Ni}_{2} \mathrm{O}_{3}+\mathrm{Fe}
$$

in the 'iron' accumulator.

One feature of such a cell will be immediately obvious. Owing to the relative positions of zine and of iron in the electrochemical series, its voltage will be unusually high for an alkaline cell. Depending somewhat on the part of the positive discharge curve used in practice, the average figure under normal conditions for the fully charged cell is about 1.86 volts, as compared with about 1.34 volts for the iron accumulator. The forty per cent increase represents a considerable advance. This is important, but the main advantage claimed by the inventor, which would seem to put the cell in a class of its own amongst transport batteries, depends on facts of quite a different nature.

No. 3254, VoL. 129] 